\title{
A quartz-wolframite-molybdenite vein and scheelite in amphibolite horizons from Thrudvang peninsula, Skjoldungen, SE Greenland
}

\author{
Diogo Rosa and Thomas Ulrich
}

During the South-East Greenland Mineral Endowment Task (SEGMENT) expedition in 2012, the possible mineral potential of the Skjoldungen region was investigated. The region is part of the Archaean North Atlantic Craton, and includes the Skjoldungen Alkaline Province (Nielsen \& Rosing 1990; Blichert-Toft et al. 1995; Kolb et al. 2013). A quartz-wolframite-molybdenite vein with phyllic alteration was identified during the reconnaissance work in the northwestern part of the peninsula of Thrudvang, close to the Kangertikajik fjord (GGU 446946; Figs 1, 2). The c. $30 \mathrm{~cm}$ wide, subvertical vein is hosted in mafic granulite. However, the deformed nature of the vein and steep terrain did not allow us to establish its extent or general trend.

Two rusty amphibolite horizons, in the mafic granulite hosting the vein, have anomalous concentrations of tungsten, but not of molybdenum (GGU 446934 and 446948; Table 1). Ultraviolet light examination conducted during the study revealed that tungsten is present as pale blue luminescing scheelite grains, rather than as wolframite, as in the vein. As such, these anomalous amphibolite samples are similar to scheelite-rich stratabound horizons documented in suprac- rustal sequences in the Godthåbsfjord region in southern West Greenland, which were interpreted by Appel \& Garde (1987) to be of exhalative origin.

\section{Fluid inclusion study}

A sample from the quartz vein (GGU 446946) was investigated for fluid inclusions in a thick section. The quartz is very transparent and shows only very few fluid inclusions which are generally aligned in secondary trails that are typically parallel and rarely crosscut each other (Fig. 3A).

The inclusions vary in size from 5 to $20 \mathrm{~mm}$ and are euhedral in shape. Only two inclusion trails showed irregular or deformed inclusion shapes. Overall, only one type of inclusion was found, characterised by a dark single phase that fills the entire inclusion (Fig. 3B).

Selected trails of 24 inclusions from three fluid inclusion assemblages were used for microthermometry, to determine the phase transition during their cooling. The dark phase in the inclusions contracted at around $-95^{\circ}$ to $-110^{\circ} \mathrm{C}$ when a small vapour bubble appeared (Fig. 3C). The inclusions
Fig. 1. Geological map of the peninsula of Thrudvang and the surrounding areas (after Kolb et al. 2013), showing the locations of the samples discussed in this paper. Contour line spacing: $100 \mathrm{~m}$.

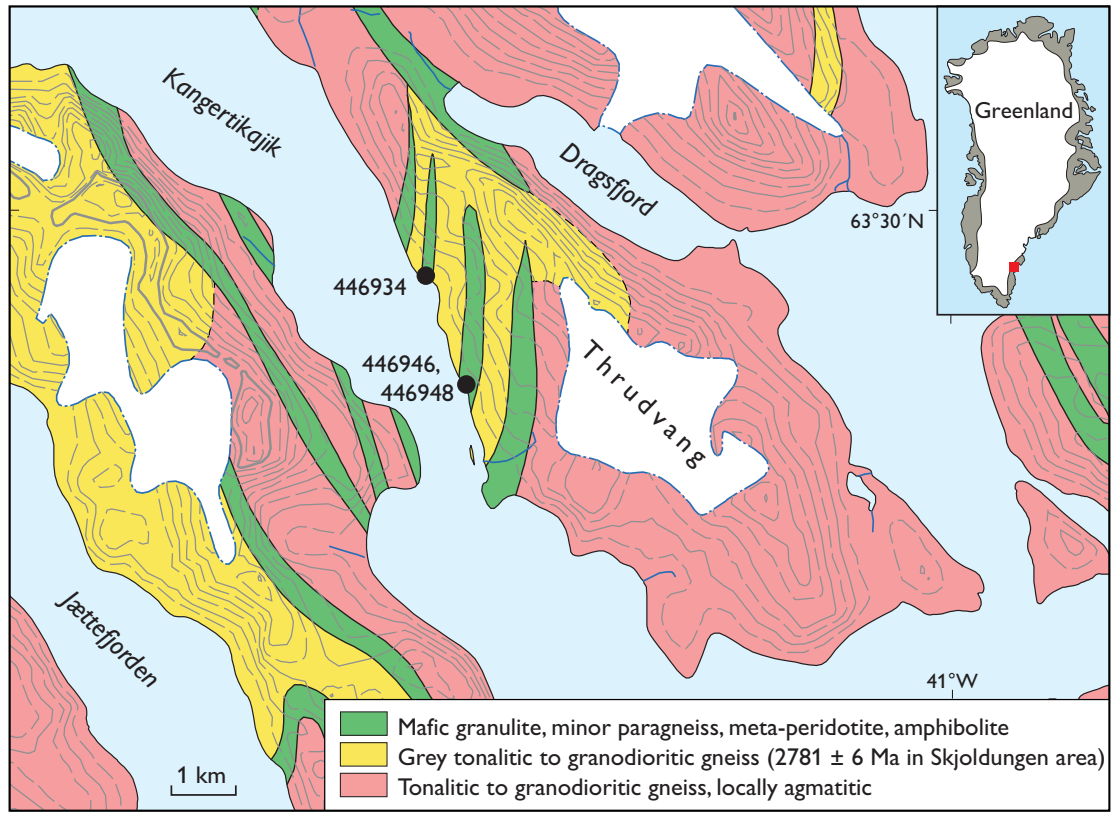


were then slowly heated at a rate of $3-5^{\circ} \mathrm{C} / \mathrm{min}$. The vapour (liquid-gas) bubble homogenised between $-59^{\circ}$ and $-50.4^{\circ} \mathrm{C}$ forming a single phase. The range of the different fluid inclu- sion assemblages in individual trails is small (Fig. 4). There was no melting of ice or clathrate observed.

The behaviour of the fluid inclusions during the microthermometric experiments is typical for high-density liquid
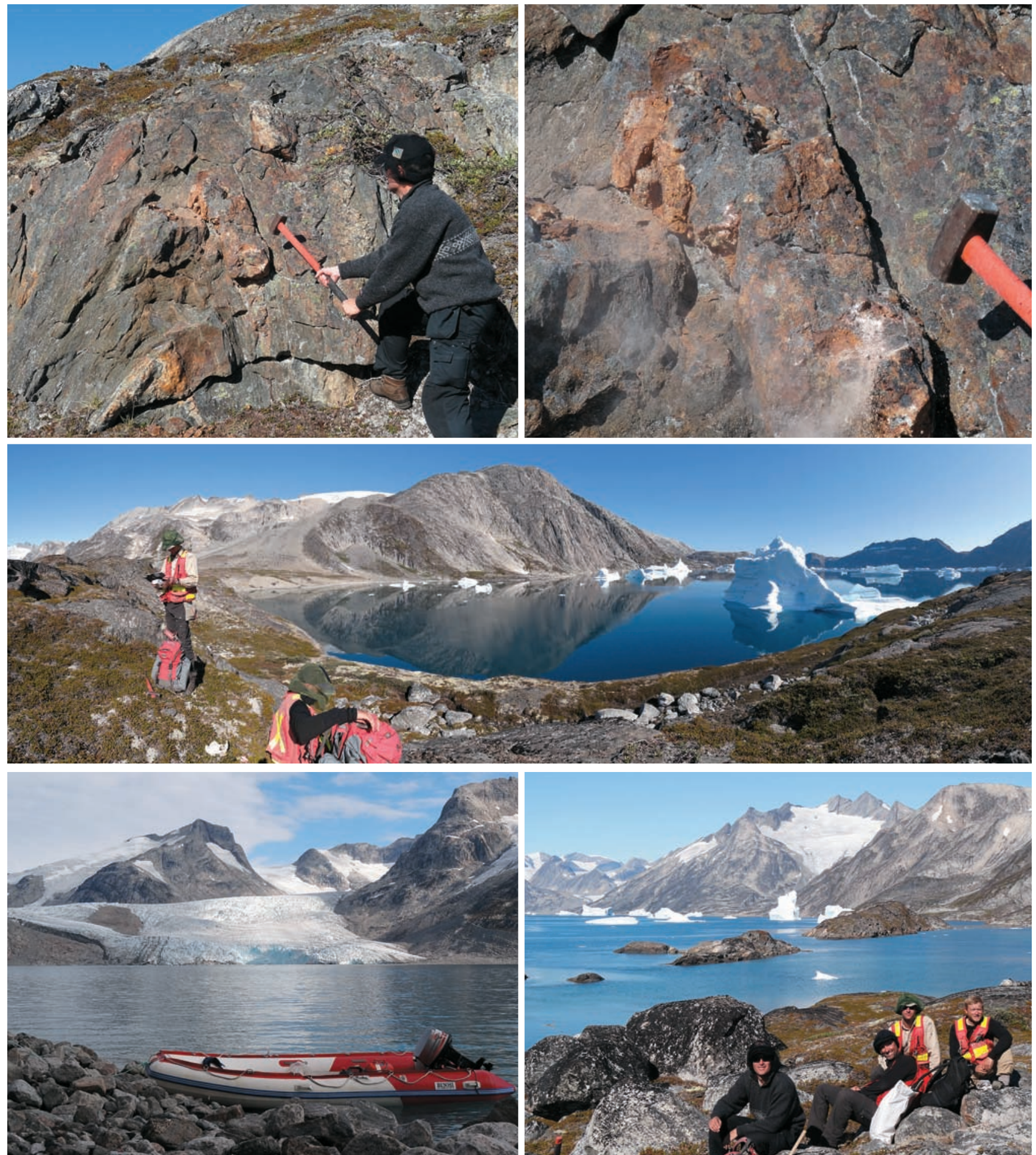

Fig. 2. Top: Sampling the vein described in this paper. Mid and bottom: Field work in the Kangertikajik fjord region, South-East Greenland in 2012. Photographs (mid and bottom): Lars Lund Sørensen. 
Table 1. Whole rock geochemistry of W-Mo mineralised samples from Thrudvang, SE Greenland *

\begin{tabular}{|c|c|c|c|c|c|c|c|c|c|c|c|c|c|c|c|}
\hline $\begin{array}{l}\text { GGU } \\
\text { no. }\end{array}$ & Description & $\begin{array}{l}\mathrm{SiO}_{2} \\
\%\end{array}$ & $\begin{array}{c}\mathrm{Al}_{2} \mathrm{O}_{3} \\
\%\end{array}$ & $\begin{array}{c}\mathrm{Fe}_{2} \mathrm{O}_{3} \\
\%\end{array}$ & $\begin{array}{c}\mathrm{MnO} \\
\%\end{array}$ & $\begin{array}{c}\mathrm{MgO} \\
\%\end{array}$ & $\begin{array}{c}\mathrm{CaO} \\
\%\end{array}$ & $\begin{array}{c}\mathrm{Na}_{2} \mathrm{O} \\
\%\end{array}$ & $\begin{array}{c}\mathrm{K}_{2} \mathrm{O} \\
\%\end{array}$ & $\begin{array}{c}\mathrm{TiO}_{2} \\
\%\end{array}$ & $\underset{\%}{\mathrm{P}_{2} \mathrm{O}_{5}}$ & $\begin{array}{c}\text { LOI } \\
\%\end{array}$ & $\begin{array}{c}\text { Total } \\
\%\end{array}$ & $\begin{array}{l}\text { Mo } \\
\text { ppm }\end{array}$ & $\begin{array}{l}W \\
\%\end{array}$ \\
\hline 446934 & $\begin{array}{l}\text { Rusty zone in } \\
\text { amphibolite }\end{array}$ & 49.75 & 14.61 & 11.18 & 0.14 & 7.39 & 10.50 & 3.14 & 0.65 & 0.84 & 0.02 & 0.89 & 99.12 & 3 & 0.37 \\
\hline 446946 & $\begin{array}{l}\text { W-Mo quartz } \\
\text { vein }\end{array}$ & 94.95 & 1.57 & 1.10 & 0.01 & 0.11 & 0.36 & 0.44 & 0.11 & 0.05 & 0.02 & 0.49 & 99.2 & 263 & 1.60 \\
\hline 446948 & $\begin{array}{l}\text { Rusty zone in } \\
\text { amphibolite }\end{array}$ & 49.03 & 13.99 & 13.05 & 0.16 & 4.77 & 12.15 & 2.81 & 0.30 & 0.74 & 0.23 & 2.18 & 99.4 & 5 & 0.55 \\
\hline
\end{tabular}

* The samples were analysed at Actlabs (Canada), using fusion ICP-OES (majors) and fusion ICP-MS (Mo and W).

$\mathrm{CO}_{2}$ inclusions that homogenise close to the $\mathrm{CO}_{2}$ triple point at $-56.6^{\circ} \mathrm{C}$. The density of the inclusions is calculated to $c .1 .1 \mathrm{~g} / \mathrm{cm}^{3}$. The range of the homogenisation temperatures indicates that a small amount of other elements such as nitrogen is probably present in the fluid.

The occurrence of one-phase liquid $\mathrm{CO}_{2}$ inclusions in metamorphic rocks was interpreted by Hollister (1990) and Johnson \& Hollister (1995) to be related to grain boundary migration during re-crystallisation of quartz. They proposed
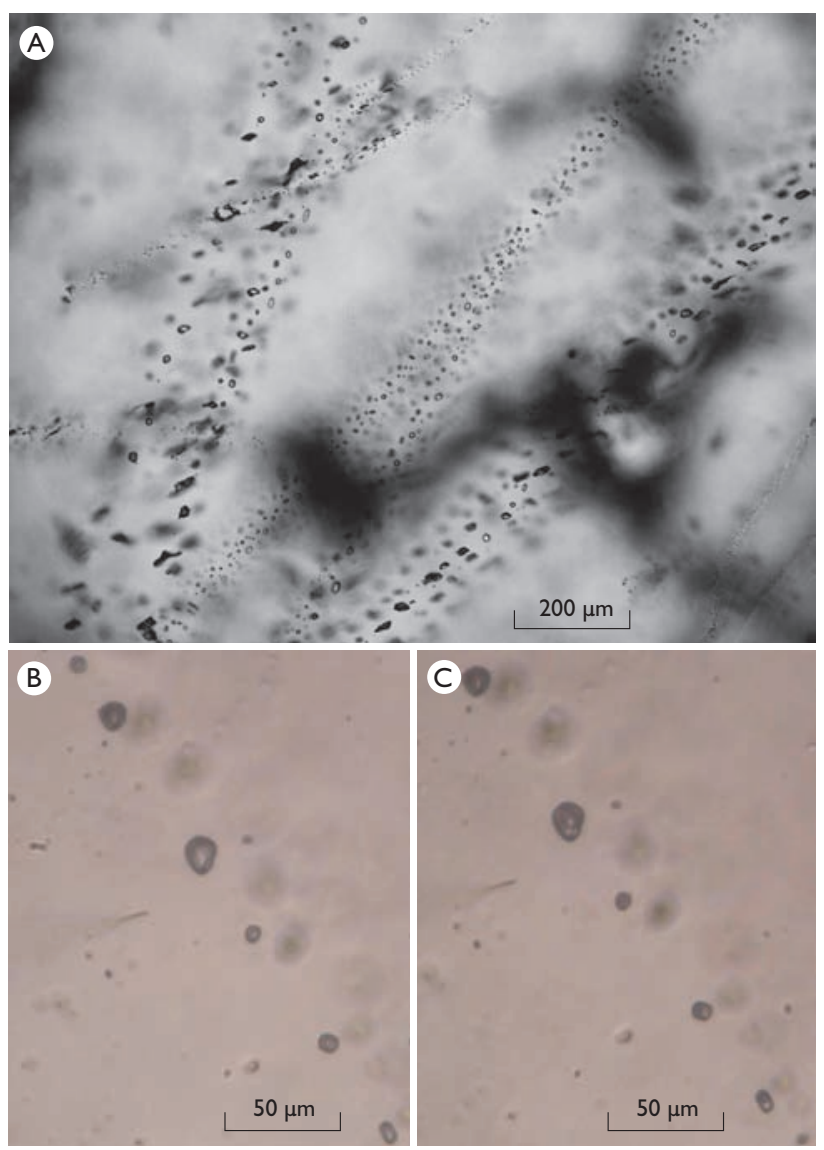

Fig. 3. Photomicrographs. A: Parallel fluid inclusion trails. B: Fluid inclusion trails with one-phase liquid $\mathrm{CO}_{2}$ inclusions at room temperature. $\mathbf{C}$ : The same fluid inclusion trails at $-120^{\circ} \mathrm{C}$. that selective removal of $\mathrm{H}_{2} \mathrm{O}$ from $\mathrm{H}_{2} \mathrm{O}-\mathrm{CO}_{2}$ fluid mixtures leads to enigmatic pure $\mathrm{CO}_{2}$ inclusions. Such processes cannot be excluded for GGU sample 446946, but are difficult to recognise. Therefore, it cannot conclusively be argued that the $\mathrm{CO}_{2}$-rich fluid is directly related to the W-Mo mineralisation observed in these rocks, because it could well be that the fluid inclusions were modified during the metamorphic history of the sample.

\section{Geochronology}

A molybdenite concentrate from the sampled vein was ReOs dated and provided a Neoarchaean age of $2749 \pm 11 \mathrm{Ma}$ (Table 2). This age is similar to the Laser Ablation Inductively Coupled Plasma Mass Spectrometry (LA-ICP-MS) date of c. $2740 \mathrm{Ma}$ for a porphyritic monzogranite and a LAICP-MS date of $2753 \pm 5 \mathrm{Ma}$ for the Skirner Bjerge Syenite in the Skjoldungen Alkaline Province, which are interpreted to have been emplaced during the first $\left(D_{S 1}\right)$ stage of regional transpression of the Skjoldungen Orogeny (Kolb et al. 2013).

The vein documents a previously unknown tungstenmolybdenum mineralisation occurrence in Greenland. Previously known molybdenite occurrences in East Greenland are related to Palaeogene intrusions. Furthermore, the age determination fits into the earliest of five Mo mineralising pulses, which, according to Golden et al. (2013), correspond to supercontinent assembly events. In the case of the Neoarchaean Mo mineralising pulse, it can be linked to the assembly of Kenorland during the Neoarchaean, also known as Superia (Golden et al. 2013).

\section{Mineral potential}

The analysed molybdenite has a relatively low Re concentration (Table 2), which is typical of Archaean molybdenite. This low Re concentration probably reflects the limited mobility of $\mathrm{Re}$ in the reducing environment that prevailed prior to oxidation of the atmosphere (Golden et al. 2013). Notwithstanding the reported secular variation of Re concentrations 
Table 2. Re-Os dating of a molybdenite occurrence at Thrudvang, SE Greenland *

\begin{tabular}{|c|c|c|c|c|c|c|c|c|}
\hline GGU & $\mathrm{Re}$ & & ${ }^{187} \mathrm{Re}$ & & ${ }^{187}$ Os & & Model age & \pm 20 \\
\hline no. & Ppm & $\pm 2 \sigma$ & Ppm & $\pm 2 \sigma$ & ppb & $\pm 2 \sigma$ & $\mathrm{Ma}$ & $\mathrm{Ma}$ \\
\hline 446946 & 54.02 & 0.14 & 33.95 & 0.09 & 1591 & 1 & 2749 & 11 \\
\hline
\end{tabular}

* Carried out at ALS Minerals (Canada), using isotope dilution mass spectrometry with a Carius-tube, solvent extraction, anion chromatography and negative thermal ionisation mass spectrometry techniques.

in molybdenite, according to Stein (2006), the Re concentration can be used to establish the type of mineral occurrence and the economic potential. However, the Re concentration in the analysed sample is intermediate between that of likely subeconomic molybdenite occurrences formed by local dehydration melting of biotite gneiss (with $<20 \mathrm{ppm}$ Re or even sub-ppm Re), and that of molybdenite of possible economic interest with a porphyry-style intrusion-related origin (with hundreds to thousands ppm Re). Therefore, we cannot discriminate between the two mineralisation types and we cannot assess the economic potential of this occurrence, using this criterion. As such, the possibility that the studied vein may be linked to an intrusion and could be part of a wider mineralising system with economic potential remains.

Finally, bearing in mind the close spatial relations, it is considered that the mineralisation in the rusty amphibolite horizons is contemporaneous with the dated vein, and not of exhalative or syn-genetic origin. In this case, the scheelite in the amphibolite horizons was precipitated in the previously carbonatised mafic to ultramafic horizons in the host package, due to their enhanced reactivity to vein-derived

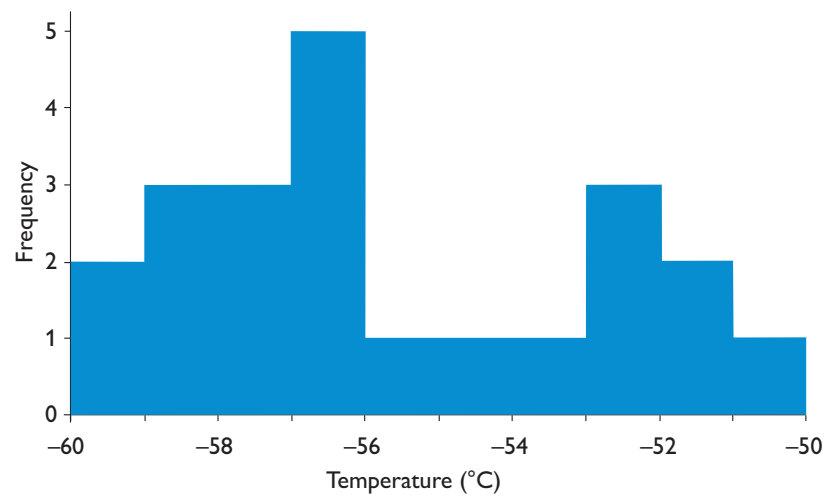

Fig. 4. Histogram of fluid inclusion homogenisation temperatures for three-phase fluid inclusions. mineralising fluids. This type of reaction can yield skarn-like occurrences, but they are probably not of economic interest - in contrast to the vein mineralisation, which could be of economic interest.

\section{Acknowledgements}

The work was carried out as part of the SEGMENT project, jointly financed by the Ministry of Industry and Mineral Resources of the Government of Greenland and the Geological Survey of Denmark and Greenland.

\section{References}

Appel, P.W.U. \& Garde, A.A. 1987: Stratabound scheelite and stratiform tourmalinites in the Archaean Malene supracrustal rocks, southern West Greenland. Bulletin Grønlands Geologiske Undersøgelse 156, $26 \mathrm{pp}$.

Blichert-Toft, J., Rosing, M.T., Lesher, C.E. \& Chauvel, C. 1995: Geochemical constraints on the origin of the Late Archean Skjoldungen alkaline igneous province, SE Greenland. Journal of Petrology 36, 515-561.

Golden, J., McMillan, M., Downs, R.T., Hystad, G., Goldstein, I., Stein, H.J., Zimmerman, A., Sverjensky, D.A., Armstrong, J.T. \& Hazen, R.M. 2013: Rhenium variations in molybdenite $\left(\mathrm{MoS}_{2}\right)$ : evidence for progressive subsurface oxidation. Earth and Planetary Science Letters $366,1-5$.

Hollister, L.S. 1990: Enrichment of $\mathrm{CO}_{2}$ in fluid inclusions in quartz by removal of $\mathrm{H}_{2} \mathrm{O}$ during crystal-plastic deformation. Journal of Structural Geology 12, 895-901.

Johnson, E.L. \& Hollister, L.S. 1995: Syndeformational fluid trapping in quartz; determining the pressure-temperature conditions of deformation from fluid inclusions in the formation of pure $\mathrm{CO}_{2}$ fluid inclusions during grain-boundary migration. Journal of Metamorphic Geology 13, 239-249.

Kolb, J., Thrane, K. \& Bagas, L. 2013: Field relationship of high-grade Neo- to Mesoarchaean rocks of South-East Greenland: tectonometamorphic and magmatic evolution. Gondwana Research 23, 471-492.

Nielsen, T.F.D. \& Rosing, M.T. 1990: The Archaean Skjoldungen alkaline province, South-East Greenland. Rapport Grønlands Geologiske Undersøgelse 148, 93-100.

Stein, H.J. 2006: Low-rhenium molybdenite by metamorphism in northern Sweden: recognition, genesis, and global implications. Lithos $\mathbf{8 7}$, 300-327.

\section{Authors' addresses}

D.R., Geological Survey of Denmark and Greenland, Øster Voldgade 10, DK-1350 Copenhagen K, Denmark. E-mail: dro@geus.dk

T.U., Department of Geoscience, Aarbus University, Hoegh-Guldbergs Gade 2, DK-8000 Aarbus C, Denmark. 